\title{
Effect of environmental factor on some litter traits of sows in the tropics Mexican
}

\section{Efecto de factores ambientales sobre algunas características de la camada de cerdas en el trópico de México}

\author{
Jesús Ek M,* M.Sc, José Segura C, Ph.D, Alejandro Alzina L, M.Sc. \\ Universidad Autónoma de Yucatán, Facultad de Medicina Veterinaria y Zootecnia, Km 15.5 carretera \\ Mérida-Xmatkuil, AP 4-116, Mérida, Yucatán, México. * Correspondencia: jeemvz@hotmail.com
}

Received: May 2014; Accepted: April 2015.

\begin{abstract}
Objective. To determine the effect of environmental factors on litter traits at birth and weaning, and their repeatabilities in four farms in the sub-humid tropics of Mexico. Materials and methods. Data from 46.249 to 50.316 litters for litter size at birth (LSB), number of piglets born alive (NBA), litter weight at birth (LWB), number of piglets weaned (NPW) and litter weight at weaning (LWW) were used. The statistical model for LSB, NBA and LWB included the effects of farm, farrowing year, farrowing season, parity number, simple interactions, random effects of sow and the error term. NPW and LWW were analyzed using the previous model plus the linear and quadratic effects of lactation length (LL). Results. The means for LSB, NBA, LWB, NPW and LWW were 11.7 piglets, 11.0 piglets, $16.1 \mathrm{~kg}, 10.3$ piglets and $61.3 \mathrm{~kg}$, respectively. All effects in the model affected the litter traits. Farrowing year $\mathrm{x}$ season interaction was significant for NPW, LWB and LWW. The dry season had the highest LSB, NBA y NPW. First parity sows had higher LSB and NBA means than for second parity sows. Parity increase until parity 4 to decrease thereafter. LL had a quadratic effect on NPW and LWW. Repeatability estimates for LSB, NBA, and LWB were $0.12,0.12$ and 0.14 , respectively. Conclusions. All traits studied were influenced by the environmental factors studied. Repeatabilities for LSB, NBA and LWB were low.
\end{abstract}

Key words: Litter size, repeatability, reproduction, seasonal variation (Source:CAB).

\section{RESUMEN}

Objetivo. Determinar el efecto de factores ambientales sobre características de la camada al nacer y al destete, y sus repetibilidades en cuatro granjas en el trópico sub-húmedo de México. Materiales y métodos. Se utilizaron los datos de 50.316 a 46.249 camadas para el total de lechones nacidos (LSB), lechones nacidos vivos (NBA) y peso de la camada al nacimiento (LWB), lechones destetados (NPW) y peso de la camada al destete (LWW). El modelo estadístico para LSB, NBA y LWB incluyen los efectos de granja, año, época, número de parto, interacciones simples, efecto aleatorio de cerda y error. El modelo para NPW y LWW incluyó los factores anteriores y además, los efectos lineal y cuadrático de largo de lactación (LL). Resultados. Las medias para LSB, NBA, LWB, NPW y LWW fueron 11.7 lechones, 11.0 lechones, $16.1 \mathrm{~kg}, 10.3$ lechones y $61.3 \mathrm{~kg}$, respectivamente. Todos los factores estudiados afectaron las características de la camada. La interacción de año x época fue significativa para NPW, LWB y LWW. La época seca presentó las mayores medias de LSB, NBA y NPW. Las cerdas primer parto obtuvieron medias de LSB y NBA superiores que las cerdas del segundo parto. Las medias 
por número de parto incrementaron hasta el cuarto, para después disminuir. La LL obtuvo un efecto cuadrático sobre NPW y LWW. Las repetibilidades estimadas para LSB, NBA, y LWW fueron 0.12 , 0.12 y 0.14 , respectivamente. Conclusiones. Todos los factores ambientales estudiados afectaron las características de la camada al nacer y al destete. Las repetibilidades estimadas fueron bajas.

Palabras clave: Repetibilidad, reproducción, tamaño de camada, variación estacional (Fuente:CAB).

\section{INTRODUCTION}

Litter size and piglet weight at birth and weaning are components of production that significantly influence the biological efficiency of sows and the profitability of farms. Hyperprolific modern sows have a high reproductive potential, which needs to be optimized according to the environmental and management conditions where they are employed. Important sources of variation in tropical regions are farm, farrowing year, farrowing season, and parity $(1,2)$. In Mexico, there are few studies on the environmental factors affecting the size and litter weight at birth and weaning of sows in commercial pig farms under sub-humid tropical conditions (3$5)$. The identification of the factors affecting those components of productivity is necessary to adequate the operation, techniques and technologies of production systems. Furthermore, knowledge of the indicators is important to make better decisions, which means a better return on investment in swine production systems in tropical Mexico.

Besides foregoing, when the best sows are selected early in life, a greater gain in productivity is expected, because highly heritable traits retain that superiority over their productive lifetime. It is therefore important to measure the extent of which this is likely to happen, through the calculation of the repeatability of the trait of interest (6).

The aim of this study was to determine the effect of some environmental factors on litter traits at birth and weaning, and to estimate the repeatability of birth traits in four farms located in the sub-humid tropics of Mexico.

\section{MATERIALS AND METHODS}

Study site. Data from the four typical commercial farms of the state of Yucatan, Mexico, were used to for this retrospective study. Yucatan is located between $19^{\circ} 30^{\prime}$ and $21^{\circ} 35^{\prime}$ north and $90^{\circ} 24^{\prime}$ west. The climate of the region is sub-humid tropical, with an average temperature of $26.6^{\circ} \mathrm{C}$, an average rainfall of $1,100 \mathrm{~mm}$, and a relative humidity of $78 \%(7)$.

\section{INTRODUCCIÓN}

Los componentes de la producción, tales como el tamaño de la camada y el peso del lechón al nacer y al destete, afectan significativamente la eficiencia biológica de las cerdas y, por consiguiente, el rendimiento de las granjas. Las cerdas modernas hiperprolíficas poseen un gran potencial reproductivo, que es necesario optimizar en función de las condiciones ambientales y de manejo en las que se utilizan. La granja, el año, la época y el número de parto $(1,2)$ son fuentes importantes de variación. En México, en granjas porcinas comerciales bajo condiciones tropicales subhúmedas, existen pocos estudios del efecto de los factores ambientales sobre el tamaño y peso de la camada al nacer y al destete (3-5). Es necesario adecuar el funcionamiento, las técnicas y las tecnologías de los sistemas de producción con el fin de identificar los factores que afectan dichos componentes de productividad. Por otra parte, en México tropical es importante el conocimiento de los indicadores para tomar mejores decisiones, lo que significa un mejor retorno sobre la inversión en los sistemas de producción porcinos.

Además de lo anterior, cuando se seleccionan las mejores cerdas en los primeros años de vida, se espera un aumento mayor de la productividad, porque las características altamente hereditarias conservan esa superioridad a lo largo de su vida productiva. Por lo tanto, es importante medir el alcance de aquellas que probablemente se presenten por medio del cálculo de la repetibilidad de la característica considerada (6).

El objetivo de este estudio realizado en cuatro granjas localizadas en las zonas tropicales subhúmedas de México fue determinar el efecto de algunos factores ambientales sobre las características de la camada al nacer y al destete y estimar la repetibilidad de sus rasgos de nacimiento.

\section{MATERIALES Y MÉTODOS}

Sitio del estudio. Para este estudio retrospectivo se utilizaron los datos procedentes de cuatro granjas comerciales típicas del estado de Yucatán, México. Yucatán está localizado entre los $19^{\circ} 30^{\prime}$ y $21^{\circ} 35^{\prime}$ de latitud norte y $90^{\circ} 24^{\prime}$ de longitud oeste. El clima de la región es tropical subhúmedo, con una temperatura promedio de $26,6^{\circ} \mathrm{C}$, una precipitación promedio de $1.100 \mathrm{~mm}$, y una humedad relativa del 78\% (7). 
Management in farms. Farms 1, 2 and 4 were full cycle farms with 3.900, 1.200 and 550 sows, respectively. Farm 3 was a two-site-type farm (breeding and production) with 320 sows. In all farms, breeding was carried out by artificial insemination; however if sows did get pregnant after three inseminations, natural mating with a boar was used. Estrus detection in sows was performed every day at 6:00 and 18:00 h using a boar, and inseminated two times (12-18 h), after estrus detection. Cross-fostering of piglets was carried out the first two days after birth in all farms. Sows were fed commercial diets according to their productive stage. Young sows (about $200 \mathrm{~kg}$ body weight) received $2.6 \mathrm{~kg} /$ day of feed with $3,000 \mathrm{kcal} \mathrm{EM} / \mathrm{kg}, 16 \%$ crude protein and $0.8 \%$ lysine; whereas sows over 300 $\mathrm{kg}$ of body weight received $3.2 \mathrm{~kg} /$ day of feed. The four farms produced their own replacements and quarantine the replacement gilts before entering the breeding herd (approximately 24 weeks of age), and they were mated after 210 day of age. Gilt and sows were vaccinated against parvovirus, leptospirosis, swine erysipelas, mycoplasmosis, and pleuropneumonia diseases.

Animals. Data from 50.316 litters from 10.340 sows for total piglets born per litter (LSB), number of piglets born alive (NBA) and litter weight at birth (LWB), and 46.249 litters from 10.065 sows for number of piglets weaned (NPW) and litter weight at weaning (LWW) were used. Data were obtained from the computer recording system (PigCHAMP ${ }^{\circledR}$ ) of the herds from 2007 to 2012. The main information used was farm name, sow identification, sow parity number, date of
Manejo en las granjas. Las granjas 1,2 y 4 eran de ciclo completo con 3.900, 1.200 y 550 cerdas, respectivamente. La granja 3 era del tipo de dos sitios (cría y producción) con 320 cerdas. En todas las granjas, la reproducción se llevó a cabo mediante inseminación artificial; sin embargo si las cerdas no quedaban preñadas luego de tres inseminaciones, se utilizó el apareamiento natural con un cerdo macho. La detección del celo en las cerdas se efectuó diariamente a las $6: 00$ y 18:00 horas usando un cerdo macho y se inseminaron dos veces (12-18 horas) después de la identificación del celo. La transferencia o adopción de lechones se llevó a cabo en todas las granjas en los primeros dos días después del nacimiento. Las cerdas se alimentaron con dietas comerciales de acuerdo con su etapa productiva. Las cerdas jóvenes (alrededor de $200 \mathrm{~kg}$ de peso corporal) recibieron $2.6 \mathrm{~kg} /$ día de alimentación con $3.000 \mathrm{kcal} \mathrm{EM} / \mathrm{kg}$ (energía metabolizante), $16 \%$ de proteína bruta y $0.8 \%$ de lisina; mientras que las cerdas de más de $300 \mathrm{~kg}$ de peso corporal recibieron $3.2 \mathrm{~kg} / \mathrm{día}$ de alimentación. Las cuatro granjas producían sus propios reemplazos y realizaban cuarentena para las cerdas jóvenes de reemplazo antes de entrar en el rebaño de cría (aproximadamente a las 24 semanas de edad), y los apareamientos después de los 210 días de edad. Las cerdas jóvenes y adultas se vacunaron contra parvovirus, leptospirosis, erisipela porcina, micoplasmosis, y enfermedades de pleuroneumonía.

Animales. Se utilizó información de 50.316 camadas procedentes de 10.340 cerdas, correspondiente al total de lechones nacidos por camada (TCN), número de lechones nacidos vivos (LNV) y peso de

Table 1. Least squares means and standard errors by source of variation for total piglets born per litter (LSB), number of piglets born alive (NBA), litter weight at birth (LWB), number of piglets weaned (NPW) and litter weight at weaning (LWW) in four farms in the sub-humid tropics of Mexico.

\begin{tabular}{|c|c|c|c|c|c|c|c|}
\hline $\begin{array}{l}\text { Source of } \\
\text { Variation }\end{array}$ & $\mathbf{n}$ & LSB & NBA & LWB (kg) & $\mathbf{n}$ & NPW & LWW (kg) \\
\hline \multicolumn{8}{|l|}{ Farm } \\
\hline 1 & 33231 & $11.9 \pm 0.03^{b}$ & $11.1 \pm 0.02^{\mathrm{b}}$ & $16.7 \pm 0.04^{a}$ & 30688 & $10.6 \pm 0.02^{a}$ & $62.1 \pm 0.19^{b}$ \\
\hline 2 & 8286 & $12.5 \pm 0.04^{a}$ & $11.4 \pm 0.04^{\mathrm{a}}$ & $16.0 \pm 0.05^{b}$ & 7589 & $10.3 \pm 0.03^{b}$ & $64.3 \pm 0.24^{a}$ \\
\hline 3 & 3546 & $9.88 \pm 0.05^{d}$ & $9.49 \pm 0.05^{d}$ & $13.3 \pm 0.08^{d}$ & 3111 & $8.2 \pm 0.05^{d}$ & $46.9 \pm 0.35^{d}$ \\
\hline 4 & 5253 & $10.42 \pm 0.04^{c}$ & $9.72 \pm 0.04^{c}$ & $14.1 \pm 0.07^{c}$ & 4861 & $9.7 \pm 0.04^{c}$ & $53.8 \pm 0.28^{c}$ \\
\hline \multicolumn{8}{|c|}{ Farrowing season } \\
\hline Dry & 16122 & $11.3 \pm 0.03^{a}$ & $10.6 \pm 0.02^{a}$ & $15.3 \pm 0.05 a$ & 14879 & $9.9 \pm 0.02^{a}$ & $57.7 \pm 0.22^{a}$ \\
\hline Rainy & 16973 & $11.2 \pm 0.03^{b}$ & $10.4 \pm 0.02^{b}$ & $15.1 \pm 0.05 b$ & 15484 & $9.6 \pm 0.02^{b}$ & $54.8 \pm 0.23^{b}$ \\
\hline Windy & 17221 & $11.0 \pm 0.03^{c}$ & $10.3 \pm 0.02^{c}$ & $14.7 \pm 0.05 c$ & 15886 & $9.6 \pm 0.02^{b}$ & $58.0 \pm 0.01^{a}$ \\
\hline \multicolumn{8}{|l|}{$\begin{array}{c}\text { Number } \\
\text { of farrowing }\end{array}$} \\
\hline 1 & 12245 & $11.1 \pm 0.0^{d}$ & $10.5 \pm 0.03^{d}$ & $14.5 \pm 0.05^{e}$ & 11361 & $9.9 \pm 0.03^{a}$ & $57.0 \pm 0.19$ ce \\
\hline 2 & 9989 & $10.7 \pm 0.0^{e}$ & $10.1 \pm 0.03^{e}$ & $15.0 \pm 0.04^{d}$ & 9273 & $9.8 \pm 0.03^{c}$ & $55.5 \pm 0.20^{d}$ \\
\hline 3 & 8271 & $11.5 \pm 0.0^{\mathrm{b}}$ & $10.9 \pm 0.03^{b}$ & $16.0 \pm 0.05^{a}$ & 7691 & $9.7 \pm 0.03^{\text {bd }}$ & $57.4 \pm 0.21^{c}$ \\
\hline 4 & 6697 & $11.6 \pm 0.0^{\mathrm{a}}$ & $11.0 \pm 0.03^{a}$ & $16.0 \pm 0.05^{a}$ & 6205 & $9.5 \pm 0.03^{e}$ & $58.2 \pm 0.24^{b}$ \\
\hline 5 & 5452 & $11.5 \pm 0.04^{b}$ & $10.7 \pm 0.04^{c}$ & $15.6 \pm 0.06^{b}$ & 5020 & $9.5 \pm 0.04 \mathrm{e}$ & $58.7 \pm 0.27^{b}$ \\
\hline 6 & 4172 & $11.3 \pm 0.04^{c}$ & $10.4 \pm 0.04^{d}$ & $15.2 \pm 0.07^{c}$ & 3638 & $9.9 \pm 0.04^{a}$ & $59.8 \pm 0.32^{\mathrm{a}}$ \\
\hline 7 & 1494 & $11.1 \pm 0.07^{\mathrm{cd}}$ & $10.3 \pm 0.07 \mathrm{e}$ & $14.6 \pm 0.12^{\mathrm{e}}$ & 1330 & $9.8 \pm 0.07^{a b c}$ & $56.2 \pm 0.57^{e}$ \\
\hline$>8$ & 1996 & $10.6 \pm 0.07^{e}$ & $9.5 \pm 0.06^{f}$ & $13.2 \pm 0.13^{f}$ & 1731 & $9.5 \pm 0.06^{\text {de }}$ & $51.6 \pm 0.61^{f}$ \\
\hline
\end{tabular}




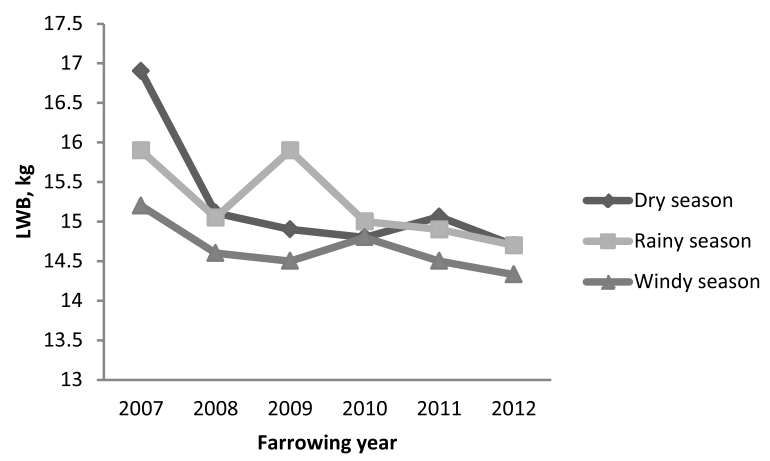

Figure 1. Year by season of farrowing interaction for litter weight at birth (LWB).

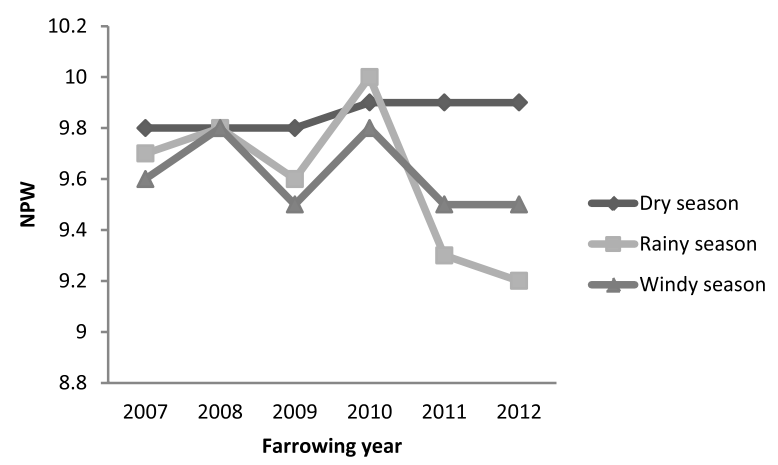

Figure 2. Year by season of farrowing interaction for number of piglets weaned (NPW).

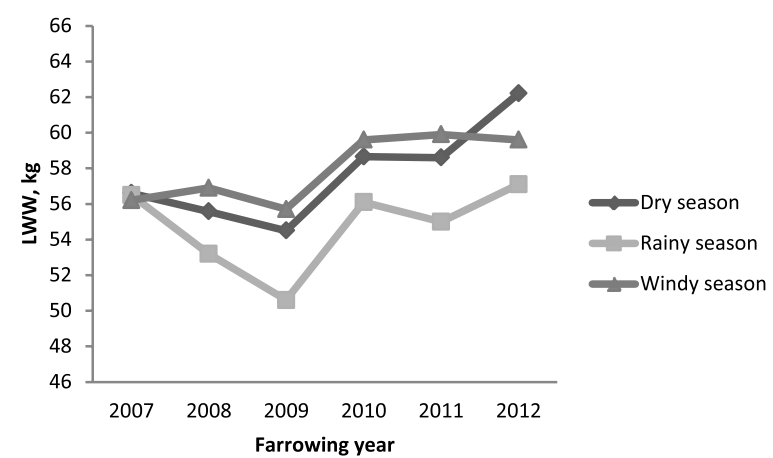

Figure 3. Year by season of farrowing interaction for litter weight at weaning (LWW).

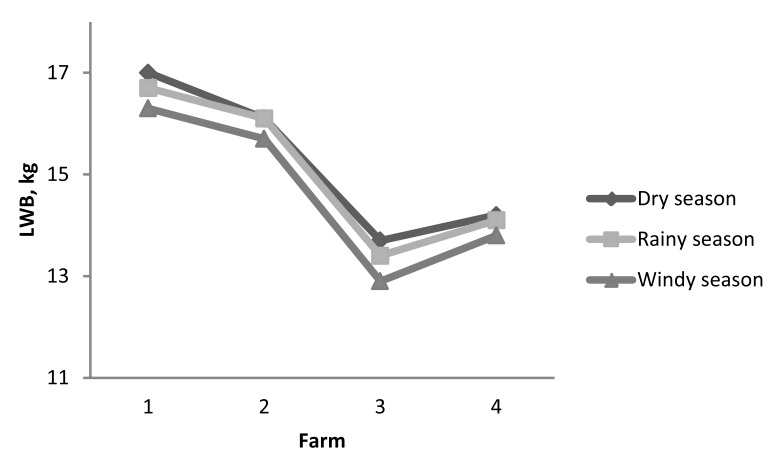

Figure 4. Farm by season of farrowing interaction for litter weight at birth (LWB).

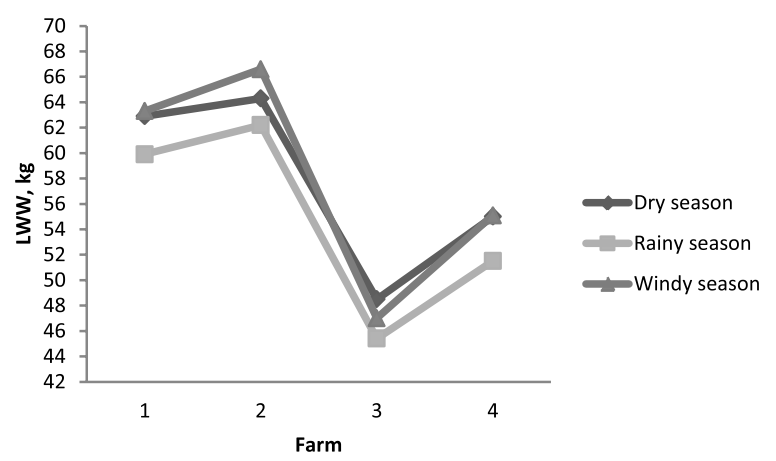

Figure 5. Farm by season of farrowing interaction for litter weight at weaning (LWW).

la camada al nacer (PCN), y también información de 46.249 camadas procedentes de 10.065 cerdas correspondiente al número de lechones destetados (LD) y peso de la camada destetada (PCD). Estos datos se obtuvieron mediante el sistema informático de registro (PigCHAMP ${ }^{\circledR}$ ) de los rebaños del año 2007 al 2012. La información principal utilizada fue el nombre de la granja, identificación y número de parto de la cerda, fecha de parto y destete, tamaño de la camada y peso en el momento del parto y del destete.

Análisis de Datos. El modelo estadístico utilizado para las variables TCN, LNV y PCN incluyó los efectos fijos de granja $[1,2,3,4]$, año de parto $(2007,2008, \ldots, 2012)$, época de parto (seca, lluviosa y con nortes), número de parto de la cerda $[1,2,3,4,5,6,7>8]$, las interacciones simples significativas, y los efectos aleatorios de cerda $(0, \sigma 2 c)$ y el error NID $(0, \sigma 2 e)$. La temporada seca comprende los meses de febrero a mayo, la lluviosa de junio a septiembre y la de nortes de octubre a enero. Las cerdas con 8 o más paridades se agruparon, debido al pequeño número de observaciones. Se analizó LD utilizando un modelo similar al descrito anteriormente, más el efecto lineal de LNV y los efectos lineales y cuadráticos de la duración de la lactancia (DL). El modelo para PCD fue similar al utilizado para LD pero incluyendo el efecto lineal de PCN en lugar del utilizado para LNV. Los análisis estadísticos se llevaron a cabo mediante el procedimiento MIXED (8).

Las estimaciones de repetibilidad y los errores estándar se calcularon solamente para TCN, LNV y PCN usando los componentes de varianza entre y dentro de las cerdas producidos mediante el procedimiento MIXED, de acuerdo con la fórmula proporcionada por Falconer y Mackay (6) y Becker (9). No se calcularon las repetibilidades para LD y PCD debido a la transferencia o adopción de lechones practicada en las granjas. 
farrowing and weaning, litter size and weight at farrowing and weaning.

Data analysis. The statistical model used for LSB, NBA and LWB included the fixed effects of farm $[1,2,3,4]$, farrowing year $(2007,2008, \ldots, 2012)$ farrowing season (dry, rainy and windy), parity number of the sow $[1,2,3,4,5,6,7>8]$, significant simple interactions, and random effects of sow $(0, \sigma 2 c)$ and the error $\operatorname{NID}(0, \sigma 2 e)$. The dry season covers the months from February to May, the rainy season from June to September and the windy season from October to January. Sows with 8 or more parities were grouped, because of small number of observations. NPW was analyzed using a model similar to that previously described, plus the linear effect of NBA and the linear and quadratic effects of lactation length (LL). The model for LWW was similar to NPW but including the linear effect of LWB instead of NBA. The statistical analyses were carried out using the MIXED procedure (8).

Repeatability estimates and standard errors were calculated only for LSB, NBA and LWB using both between and within sow components of variance produced by the MIXED procedure, according to the formula provided by Falconer and Mackay (6) and Becker (9). Repeatabilities for NPW and LWW were not calculated because of cross-foster of piglets practiced in the farms.

\section{RESULTS}

The overall means and standard deviations for LSB, NBA, LWB, NPW and LWW were $11.7 \pm 3.11$ piglets, $11.0 \pm 3.02$ piglets, $16.2 \pm 4.35 \mathrm{~kg}, 10.3 \pm 3.12$ piglets and $61.3 \pm 20.0 \mathrm{~kg}$, respectively. Lactation length had a mean and standard deviation of $22.4 \pm 2.9$ days.

All the factors and interactions included in the models were significant $(p<0.05)$ on the five response variables. The least squares means for the main factors are shown in table 1.

The interaction of year $x$ season of farrowings was significant for LWB, NPW, and LWW (Figure 1,2 and 3, respectively). The highest mean at different season vary with the year. figure 1 and 2 show no trend; with means in different seasons and years; however, figure 3 results shows a trend of increasing LWW starting in 2009. The interaction between farm and farrowing season was significant for LWB and LWW. Figure 4 and 5 show different means of LWB and LWW for farms in different season.

\section{RESULTADOS}

Las medias generales y las desviaciones estándar para TCN, LNV, PCN, LD y PCD fueron $11.7 \pm 3.11$ lechones, $11.0 \pm 3.02$ lechones, $16.2 \pm 4.35$ $\mathrm{kg}, 10.3 \pm 3.12$ lechones y $61.3 \pm 20.0 \mathrm{~kg}$, respectivamente. La duración de lactancia tuvo una media y una desviación estándar de $22.4 \pm 2.9$ días.

Todos los factores e interacciones incluidas en los modelos son significativas $(p<0.05)$ para las cinco variables de respuesta. En la Tabla 1 se muestran Las medias de mínimos cuadrados para los factores principales.

La interacción entre el año de parto y la época de parto es significativa para PCN, LD y PCD (Figura 1,2 y 3, respectivamente). La media más alta en las diferentes temporadas varía con el año. Las figuras 1 y 2 no muestran ninguna tendencia con las medias en diferentes épocas y años; sin embargo, los resultados de la Figura 3 muestran una tendencia al aumento de PCD iniciando en el año 2009. La interacción entre el efecto granja y la época de parto es significativa para PCN y PCD. Las figuras 4 y 5 muestran diferentes medias de PCN y PCD para las granjas en diferentes temporadas.

La granja 2 tuvo las medias más altas para TCN, LNV y PCD; la granja 1 tuvo las medias más altas para PCN y LD; y la granja 3 tuvo el peor desempeño. En la temporada seca se presentaron los valores más altos para TCN, LNV, PCN y LD, y la temporada lluviosa el valor más bajo de PCD. Las cerdas del primer parto tuvieron valores más altos de TCN y LNV que las del segundo parto $(p<0.05)$, aumentaron posteriormente hasta el cuarto parto y luego disminuyeron en los siguientes partos. El valor más alto de PCN se obtuvo en los partos 3 y 4 , y el mayor LD se encontró en los partos 1 y 6 ; el mayor PCD se encontró en las cerdas del parto 6 .

La duración de la lactancia tiene efectos lineales negativos $(-1.3 \pm 0.056)$ y cuadráticos positivos $(0.037 \pm 0.001)$ sobre LD, y efectos lineales positivos (3.22 \pm 0.27$)$ y cuadráticos negativos $(-0.012 \pm 0.005)$ sobre PCD. La variable LNV tiene un efecto lineal positivo $(0.014 \pm 0.004)$ y la variable PCN tiene un efecto lineal positivo $(0.14 \pm 0,019)$ sobre LD y PCD, respectivamente.

Los valores correspondientes a la repetibilidad estimada y los errores estándar para TCN, LNV y PCN fueron $0.13 \pm 0.004,0.12 \pm 0.004$ y $0.14 \pm 0.004$, respectivamente. 
Farm 2 had the highest means for LSB, NBA and LWW; farm 1 had the highest means for LWB and NPW; and farm 3 had the worst performance. The dry season had the highest LSB, NBA, LWB and NPW, and the rainy season the lowest LWW. First parity sows had higher LSB and NBA than second parity $(p<0.05)$, to increase thereafter until fourth parity and then decreased in the following farrowings. The highest LWB was obtained in farrowings 3 and 4 , and the largest NPW was found in both farrowings 1 and 6; the largest LWW was found in sows of parity 6 .

Lactation length has negative linear $(-1.3 \pm 0.056)$, and positive quadratic $(0.037 \pm 0.001)$, effects on NPW, and positive linear (3.22 \pm 0.27$)$ and negative quadratic $(-0.012 \pm 0.005)$ effects on LWW. Positive linear effect of NBA $(0.014 \pm 0.004)$ and positive linear effect of LWB $(0.14 \pm 0.019)$ on NPW and LWW_respectively.

The repeatability estimates and standard errors for LSB, NBA, and LWB were $0.13 \pm 0.004,0.12 \pm$ 0.004 and $0.14 \pm 0.004$, respectively.

\section{DISCUSSION}

The overall means and standard deviations for LSB and NBA were lower than those reported by Abell et al (10) in USA (14.8 and 11.6 pigs, respectively). However, the means here found are higher than mean reported by Diaz et al (11) in Colombia, who obtained 10.8 pigs for NBA. The LWB mean was similar than the mean reported by Chansomboon (1) in Thailand with $16 \mathrm{~kg}$, and higher than those reported by Fraga et al (12) in Brazil and Gourdine et al (13) in Guadeloupe with $15.0 \mathrm{~kg}$ and $14.0 \mathrm{~kg}$, respectively. Schwarz et al (14) reported a lower NPW mean (8.4 pigs) in Polish Large White sows. Also, Chansomboon et al (1), Diaz et al (11) and Gomez-Medina et al (5) reported means of 8.57, 10 and 9.44 pigs, respectively. The LWW mean here found is lower than that reported by Gourdine et al (13); however it is similar to the $60.8 \mathrm{~kg}$ reported by Sai et al (15). The differences in mean values may be due to geographical location, management and application of differences technologies, and commercial breeds used, as well as population structure and the presence or not of diseases in farms.

The effect of farm on litter traits at birth and weaning has been reported by other authors $(1,16,17)$. Farm differences primarily involves the skills and training of staff, housing systems, genetics of the reproductive herd, number of sows, average number of farrowing and implementation of reproductive and feeding techniques provided to the sow in the area of farrowing and lactation.

\section{DISCUSIÓN}

Las medias y desviaciones estándar generales para TCN y LNV fueron más bajas que las reportadas por Abell et al (10) en EE.UU. (14.8 y 11.6 cerdos, respectivamente). Sin embargo, las medias aquí encontradas son superiores a las reportadas por Díaz et al (11) en Colombia, quienes obtuvieron $10, .8$ cerdos para LNV. La media para PCN es similar a la reportada por Chansomboon (1) en Tailandia con $16 \mathrm{~kg}$, y mayor a la reportada por Fraga et al (12) en Brasil y Gourdine et al (13) en Guadalupe con $15.0 \mathrm{~kg}$ y $14.0 \mathrm{~kg}$, respectivamente. Schwarz et al (14) reportaron una media para LD inferior (8.4 cerdos) en las cerdas polacas Large White. También, Chansomboon et al (1), Díaz et al (11) y Gómez-Medina et al (5) reportaron medias de $8.57,10$ y 9.44 cerdos, respectivamente. La media para PCD aquí encontrada es inferior a la reportada por Gourdine et al (13); sin embargo es similar a los $60.8 \mathrm{~kg}$ reportados por Sai et al (15). Estas diferencias de las medias se deben principalmente a la ubicación geográfica, manejo y aplicación de diferentes tecnologías y razas comerciales utilizadas, así como a la estructura poblacional y la presencia o no de enfermedades en las granjas.

Otros autores $(1,16,17)$ han informado acerca del efecto de granja sobre las características de la camada al nacer y al destete. Las diferencias entre las granjas involucran principalmente las habilidades y el entrenamiento del personal, sistemas de alojamiento, genética del rebaño reproductivo, número de cerdas, número promedio de partos y la aplicación de técnicas de alimentación y de reproducción proporcionadas a la cerda en el área de partos y lactancia.

El efecto del año de parto se reportó para TCN y $\operatorname{LNV}(2,16,17)$. Es difícil explicar las causas de las diferencias entre los años estudiados en este trabajo, pero se podría atribuir a diferentes condiciones de manejo, diferencias de condiciones climáticas o a la experiencia del personal en el manejo de las cerdas.

La interacción entre el año y la época de parto es significativa para PCN, LD y PCD, de manera similar a los resultados reportados por otros autores, bajo condiciones tropicales $(1,18,19)$. Las diferencias para PCN y LD pueden ser debido a diferentes condiciones sanitarias y de manejo entre las temporadas y los años (Figura 1 y 2). Además, las prácticas de manejo adecuado pueden mejorar el PCD; la tendencia de aumento de PCD puede deberse al aumento del consumo de alimento. Sin embargo, la temporada lluviosa presentó las medias más bajas de PCD en todos los años (Figura 3). Se reportó que la combinación de alta temperatura y alta humedad durante la temporada lluviosa 
Effect of farrowing year has been reported for LSB and NBA $(2,16,17)$. Causes of the differences between years studied in this work are difficult to explain but might be attributed to different management conditions, differences in climatic conditions or staff experience in sows management.

The interaction of year by season of farrowing was significant for LWB, NPW and LWW, similar to the results reported by other authors, under tropical conditions $(1,18,19)$. The differences for LWB and NPW could be due to management and sanitary differences between seasons and years (Figure 1 and 2). Additionally, appropriate management practices can improve LWW, the trend of increasing LWW might be due to increasing feed intake. However, the rainy season showed lowest means of LWW in all years (Figure 3). The combination of high temperature and high humidity during the rainy season has been reported to be partly associated with reduced appetite (17). According to Chambonson et al (1) the interaction is the result of the combined effects of nutrition (nutritional content and composition of diets), climate (seasonal fluctuations in humidity and temperature), and management during the different years.

The effect of season or month on LSB and NBA in tropical regions has been reported by other authors $(2,5,16,17,18)$. Suriyasomboon et al (17) and Tummaruk et al (2) indicate that in the tropics regions the effect of season is due to the high environmental temperature, high humidity, and to a lesser extent to changes in the photoperiod. Negative effect of high ambient temperature affects reproductive traits of sows, either by acting directly on ovarian function or to the hypothalamic-pituitary-ovarian axis level (17). Also, in tropical areas such as Thailand and Brazil, Suriyasomboon et al $(20,21)$ and Freneau et al (22) indicate that the high temperatures have a significant negative effect on ejaculate volume, total sperm counts and the morphology of the spermatozoa of the boars.

Table 1 shows a decrease in LSB and NBA from first to second parity, a phenomenon known as the syndrome of the second litter, which has been reported by other authors $(23,24)$. Hoving et al $(24)$ and Schenkel et al (25) indicate that the reduction in litter size after the first farrowing is probably due to a lower rate of ovulation and to an increase in embryo mortality because gilts are more susceptible to lose weight during lactation and have not finished their corporal development yet. First farrowing females with larger NBA may have not enough feed intake during lactation to fulfill their nutritional requirements, so that embryonic survival (and subsequent litter size) in these females is reduced. está parcialmente asociada con una reducción del apetito (17). Según Chansonboom et al (1), esta interacción es la consecuencia de los efectos combinados de nutrición (contenido nutricional y composición de dietas), clima (fluctuaciones estacionales de humedad y temperatura), y manejo durante los años de estudio.

Otros autores $(2,5,16,17,18)$ han reportado el efecto de la época o mes de parto sobre el TCN y LNV en regiones tropicales. Suriyasomboon et al (17) y Tummaruk et al (2) indican que en las regiones tropicales el efecto de la temporada se debe a la alta temperatura ambiental, alta humedad y en menor grado a los cambios del fotoperiodo. La alta temperatura ambiental tiene un efecto negativo sobre las caracteristicas reproductivas de cerdas, ya sea actuando directamente sobre la función ovárica o a nivel del eje hipotálamo-hipófisis-ovárico (17). También, en áreas tropicales tales como Tailandia y Brasil, Suriyasomboon et al $(20,21)$ y Freneau et al (22) indicaron que las altas temperaturas tienen un efecto negativo significativo sobre el volumen de eyaculado, total de recuento de esperma y morfología de los espermatozoides de los cerdos macho.

La Tabla 1 muestra una disminución de TCN y LNV del primer al segundo parto, un fenómeno conocido como el síndrome de la segunda camada, que ha sido reportado por otros autores $(23,24)$. Hoving et al (24) y Schenkel et al (25) indican que la reducción del tamaño de la camada después del primer parto se debe probablemente a una baja tasa de ovulación y a un incremento de la mortalidad embrionaria. Esto es causado porque las cerdas jóvenes son más susceptibles a perder peso durante la lactancia y aún no han terminado su desarrollo corporal. Es posible que las hembras de primer parto con mayores LNV no hayan recibido suficiente alimentación durante la lactancia para satisfacer sus requerimientos nutricionales, por lo que en estas hembras se reduce la supervivencia embrionaria (y por consiguiente el tamaño de la camada).

Otros autores han reportado el efecto del número de parto sobre TCN y LNV $(2,16,17,26)$. Además el efecto del número de parto sobre PCN, LD y PCD ha sido reportado por Tantasuparuk et al (18) y Chansomboon et al (1). El aumento habitual del tamaño de la camada hasta el parto 4 se debe probablemente a un incremento de la tasa de ovulación, la capacidad uterina y la edad de la cerda (27).

La repetibilidad estimada para $\mathrm{TCN}$ es ligeramente menor (0.14) a la reportada por Nguyen et al (28); mientras que la repetibilidad para LNV es menor a la estimada (0.27) reportada por Adeoye 
The effect of parity number on LSB and NBA has been reported by other authors $(2,16,17,26)$. Also, the effect of parity number on LWB, NPW and LWW has been reported by Tantasuparuk et al (18) and Chansomboon et al (1). The usual increase in litter size up to parity 4 is probably due to the increase in ovulation rate, uterine capacity and age of the sow (27).

Estimated repeatability for LSB is slightly lower than that (0.14) reported by Nguyen et al (28); whereas repeatability for NBA is lower than the 0.27 estimate reported by Adeoye et al (29) in native pigs in Nigeria, which is similar that reported by Segura et al (30) under the same conditions of the current study (0.12); however, is higher than the repeatability estimate $(0.09)$ found by Nguyen et al (28). The repeatability here estimated for LWB is higher than that $(0.11)$ reported by Adeoye et al (29), but equal to that (0.13) reported by Segura et al (30). According to Segura et al (30) the difference between repeatability estimates may be due to differences between breeds or genetic commercial lines, environmental conditions and management and statistical methods used. The repeatability means of estimated in this study were low suggesting that to improve these characteristics is more important to improve the management that to use genetic methods.

In conclusion, under the conditions of this study, all the environmental factors studied were important sources of variation for all litter traits at birth and weaning. Therefore all of them should be considered in production programs to improve management strategies and herd feeding in order to reduce the effect of both season farrowing and number parity to improve farm's productivity and profitability. Repeatability estimates were low but within the values reported in the literature. et al (29) en cerdos nativos en Nigeria, lo que es similar a lo reportado por Segura et al (30) en las mismas condiciones del presente estudio (0.12); sin embargo, es más alta que la repetibilidad estimada (0.09) encontrada por Nguyen et al (28). La repetibilidad aquí estimada para PCN es mayor que (0.11) la reportada por Adeoye et al (29), pero igual (0.13) a la reportada por Segura et al (30). Según Segura et al (30), la diferencia entre las repetibilidades estimadas puede ser causada por las diferencias entre razas o líneas comerciales genéticas, condiciones ambientales y de manejo y los métodos estadísticos utilizados. La repetibilidad promedio estimada en este estudio fue baja, lo que sugiere que para mejorar estas características es más importante optimizar el manejo que utilizar métodos genéticos.

En conclusión, bajo las condiciones de este estudio, todos los factores ambientales analizados fueron importantes fuentes de variación para todas las características de la camada al nacer y al destete. Por lo tanto, se deben considerar todos estos factores en los programas de producción para mejorar las estrategias de manejo y alimentación del hato con el fin de reducir el efecto tanto de la época como del número de parto, y por consiguiente optimizar la productividad y rentabilidad de la granja. La estimación de las repetibilidades fueron bajas pero se encuentra dentro de los valores reportados en la literatura.

\section{REFERENCES}

1. Chansomboon C, Elzo MA, Suwanasopee T, Koonawootrittriron S. Estimation of genetic parameters and trends for weaning-tofirst service interval and litter traits in a commercial landrace-large white swine population in northern Thailand. Asian-Aust J Anim Sci 2010; 23:543-555.

2. Tummaruk $P$, Tantasuparuk $M$, techakumphu $M$, Kunavongkrit A. Seasonal influences on the litter size at birth of pigs are more pronounced in the gilt than sow litters. J Agri Sci 2010; 148:421-432.
3. Segura CJ, Segura CV. Influencia de algunos factores genéticos y ambientales sobre la eficiencia reproductiva de cerdos en una granja de la Chontalpa, Tabasco. Vet Méx $1991 ; 12: 73-76$.

4. Chimal P, Segura JC. Estimates of breed average direct, maternal and heterosis effects for some productive traits of swine in the Mexican tropics. Rev Brasil Genet (Brazil J Genetics) 1994; 17:267-271. 
5. Gómez-Medina M, Segura-Correa J, Rodríguez-Buenfil J. 1999. Efecto de año, bimestre y número de parto de la cerda en el tamaño y peso de la camada al nacer y al destete en una granja comercial. Rev Biomed 1999; 10:23-28.

6. Falconer DS, Mackay TFC. Introducción a la genética Cuantitativa. $4^{a}$ ed. Zaragoza, España: Editorial Acribia, S.A. 2006.

7. Instituto Nacional de Estadistica y Geografia (INEGI). Anuario Estadístico de los Estados Unidos Mexicanos 2010. Aguascalientes, Ags: INEGI; 2010.

8. SAS Institute Inc. ${ }^{\circledR}$ : Guide for Personal computer [programa de ordenador]. Versión 9.2. Cary (NC): SAS Institute IC.; 2008.

9. Becker WA. Manual of Quantitative Genetics. 5th Ed. Pullman, Washington: Academic Enterprises; 1992.

10. Abell CE, Mabry JW, Dekkers JCM, Stalder $\mathrm{KJ}$. Genetic and phenotypic relationships among reproductive and post-weaning traits from a commercial swine breeding company. Livest Sci 2012; 145:183-188.

11. Díaz C, Rodríguez N, Vera V, Ramírez G, Casas G, Mogollón J. Caracterización de los sistemas de producción porcina en las principales regiones porcicolas colombianas. Rev Colomb Cienc Pecu 2011; 24:131-144.

12. Fraga $A B$, Araújo $F$, Azevedo $A P$, Silva $F$, Santana $R$, Machado $D$, et al. Peso médio do leitão, peso e tamanho de leitegada, natimortalidade e mortalidade em suínos no Estado de Alagoas. Rev Bras Saúde Prod An 2007; 8:354-363.

13. Gourdine JL, Quesnel H, Bidanel J, Renaudeau D. Effect of season, parity and lactation on reproductive performance of sows intropical humid climate. Asian-Aust J Anim Sci 2006; 8:1111-1119.

14. Schwarz T, Nowicki J, Tuz R. Reproductive performance of Polish Large White sows in intensive production-efect of parity and season. Ann Anim Sci 2009; 3:269-277.

15. Sai PJ, Gnana PM, Gupta BR, Mahender. Genetic study on reproductive traits in crossbred pigs. Liv Res Rural Develop [en línea] 2009; (acesso 26 de febrero de 2013) 21(9). URL Disponible en: http://www.Irrd. org/Irrd21/9/pras21142.htm
16. Tummaruk $\mathrm{P}$, Tantasuparuk $\mathrm{W}$, Techakumphu $M$, Kunavongkrit A. Effect of season and outdoor climate on litter size at birth in purebred Landrace and Yorkshire sows in Thailand. J Vet Med Sci 2004;66:477-82.

17. Suriyasomboon A, Lundeheim N, Kunavongkrit A, Einarsson S. Effect of temperature and humidity on reproductive performance of crossbred sows in Thailand. Theriogenology 2006; 65:606-628.

18. Tantasuparuk W, Lundeheim N, Dalin AM, Kunavongkrit A, Einarsson S. Reproductive performance of purebred Landrace and Yorkshire sows in Thailand with special reference to seasonal influence and parity number. Theriogenology 2000; 54:481-96.

19. Pholsing $\mathrm{P}$, Koonawootrittriron S, Elzo $M$, Suwanasopee T. Genetic association between age and litter traits at first farrowing in a commercial Pietrain-Large White population in Thailand. Kasetsart J Nat Sci 2009; 43:280-287.

20. Suriyasomboon A, Kunavongkrit $A$, Lundeheim N, Einarsson S. Effect of temperature and humidity on sperm production in Duroc boars under different housing systems in Thailand. Livest Prod Sci 2004; 89:19-31.

21. Suriyasomboon A, Kunavongkrit $A$, Lundeheim N, Einarsson S. Effect of temperature and humidity on sperm morphology in Duroc boars under different housing systems in Thailand. J Vet Med Sci 2005; 67:777-785.

22. Freneau GE, Ferreira JD, Sobestiansky J. Avaliação das caracteristicas seminais de varrões mantidos em centrais de inseminação artificial com ambiente climatizado e não climatizado durante 12 meses. Ci Anim Bras, Goiânia 2012; 4:466478.

23. Saito H, Sasaki $Y$, Hoshino $Y$, Koketsu $Y$. The occurrence of decreased numbers of pigs born alive in parity 2 sows does not negatively affect herd productivity in Japan. Livest Sci 2010; 128:189-192.

24. Hoving LL, Soede NM, Graat EAM, Feitsma $H$, Kemp B. Reproductive performance of second parity sows: Relations with subsecuente reproduction. Livest Sci 2011; 140:124-130. 
25. Schenkel AC, Bernardi ML, Bortolozzo and Wentz I. 2010. Body reserve mobilization during lactation in first parity sows and its effect on second litter size. Livest Sci 210; 132:165-172.

26. Ordaz-Ochoa G, Juárez-Caratachea A, García-Valladares A, Pérez-Sánchez E, Ortiz-Rodríguez R. Efecto del número de parto sobre los principales indicadores reproductivos de las cerdas. Revista Científica FCV-LUZ 2013; 23:511-519.

27. Foxcroft GR, Dixon WT, Novak S, Putman CT, Town SC, Vinsky MD. The biological basis for prenatal programming of postnatal performance in pigs. J Anim Sci 2006; 84 Suppl:E105-112.
28. Nguyen $\mathrm{NH}$, McPhee $\mathrm{CP}$, Wade $\mathrm{CM}$. Genetic variation and responses in reproductive performance of sows in lines selected for growth rate under restricted feeding. Anim Sci 2006 ; 82:7-12.

29. Adeoye AA, Adeogun IO, Akinokun JO. Repeatability of litter traits of Nigerian indigenous sows. Liv Res Rural Develop (en linea) 2003; (fecha de acceso 26 de febrero de 2013) 15:1-6; URL disponible en: http:// www.Irrd.org/Irrd15/2/adeo152.htm

30. Segura CJ, Alzina A, Ek JE, Segura VM. Estimadores de índices de constancia para características de la camada al nacimiento e intervalo entre partos de cerdas utilizando aproximaciones de máxima verosimilitud restringida y bayesianas. Revista Científica, FCV-LUZ 2013; 23:54-58. 